\title{
Disembodied Vocal Innocence: John Addington Symonds, the Victorian Chorister, and Queer Musical Consumption
}

\author{
FRASER RIDDELL
}

Et $\hat{o}$, ces voix d'enfants chantant dans la coupole! —Paul Verlaine, "Parsifal"1

$\mathbf{I}_{\mathrm{w}}^{\mathrm{N}}$ $\mathrm{N}$ the early 1890s, both John Addington Symonds and Arthur Symons were fascinated by Paul Verlaine's sonnet "Parsifal" (1886) —in particular, by its final line, which dwells on the voices of singing children. Symonds enthused to Symons that it was "a line [to] treasure forever," while, nevertheless, noting his reservations to Horatio Forbes Brown that "fine as it is, [it] looks like it [. . .] must be rather of the sickly school." 2 In an article on Verlaine, Symons praised the poem as a "triumph [of] amazing virtuosity," echoing the sentiments of his friend George Moore, who in Confessions of a Young Man (1886) exclaimed that he "kn[ew] of no more perfect thing than this sonnet." ${ }^{3}$ With its repetition of assonant vowel sounds, Verlaine's closing line captures the gentle rise heavenward of the ethereal voices of Richard Wagner's offstage choristers, resounding above the stage at the conclusion of the opera. The hiatus with which the line opens functions as a sigh of renunciation, as the listeners abandon themselves to the inexpressible force of the transcendent. In Verlaine's sonnet, these children's voices become the epitome of the "disembodied voice" that Symons sees as so characteristic of Decadent poetics. ${ }^{4}$ They sing of the delicate immateriality of spiritual experience, the transient fragility of existence.

Curiously, when Symonds first recalled the line-in the letter to Horatio Forbes Brown cited above-he misremembered it, so that the children do not sing out of sight, in the dome of a cathedral ("dans la coupole"), but are rendered more immediately present "in the chorus"

Fraser Riddell is a departmental lecturer in English literature at Trinity College, University of Oxford. He recently received his doctorate from Durham University for a thesis on "Music and the Queer Body in Fin-de-Siècle Literature," which focused on works by J. A. Symonds, Walter Pater, Vernon Lee, and E. M. Forster. His current project examines the significance of tactile sensory perception and embodied cognition in Victorian literature and culture.

Victorian Literature and Culture, Vol. 48, No. 3, pp. 485-517.

(C) The Author(s), 2020. Published by Cambridge University Press. This is an Open Access article, distributed under the terms of the Creative Commons Attribution licence (http://creativecommons.org/ licenses/by/4.0/), which permits unrestricted re-use, distribution, and reproduction in any medium, provided the original work is properly cited.

doi:10.1017/S1060150319000020 
("dans la chœur"). Symonds's mistake is a significant one because it points to a broader tension in his own writings, and in Victorian culture more generally, between the child's singing voice as a disembodied emblem of idealized beauty and the bodily materiality of a singing voice that becomes the object of "sickly" desire. Verlaine's final line awakens in Symonds the memory of his own experiences as a young man, in which the voice of a chorister-singing before him "dans la chœur"-first prompted the stirrings of his queer sexual desire.

Symonds's desires for the singing voices of prepubescent boys can best be understood by situating them within the wider Victorian context of eroticized childhood innocence. In doing so, it becomes possible to articulate the significance of ideas of disembodiment - the denial of the body-that attach to such voices. Drawing attention to the manner in which the vocal "innocence" of the chorister is produced reveals the role of Victorian musical culture in indirectly contributing to the eroticization of children. More generally, the pederastic listening practices engaged in by Symonds and his contemporaries present a challenge to the frequent romanticization in queer studies of the singing voice as a space in which sexual desire might be freely and unproblematically explored.

Recent work in queer studies and queer musicology has emphasized, in a variety of ways, the significance of the singing voice in articulations of the queer desiring body. One strand of criticism explores the queer potential of gender-indeterminate voices that refuse to match their sexed bodies, such as that of the castrato. ${ }^{5}$ Patricia Pulham, for example, has argued that the voice of the castrato in Vernon Lee's "A Wicked Voice" (1890) is a "potent symbol of [lesbian] empowerment." From a more general perspective, Roland Barthes's paeans to the pleasures of the embodied singing voice in essays such as "Le Grain de la Voix" ("The Grain of the Voice") form part of what D. A. Miller has called the "gay male cultural project of resurrecting the flesh." ${ }^{7}$ In similar terms, Wayne Koestenbaum's The Queen's Throat has playfully celebrated the operatic voice-particularly the female voice-as a flamboyant emblem of sexual desire. For Koestenbaum, the emotionally overwhelming experience of listening to the operatic voice dissolves the safe boundaries of subjectivity in a way that might liberate and empower the queer listener. The intense identification of queer listeners with the operatic diva arises, he suggests, because the diva's forcefully visceral voice offers a space in which desire is triumphantly and proudly theatricalized. Such work has often appeared to suggest that the (queer) pleasures one might 
discover in the singing voice are limitless. Yet, in doing so, such critics have often overlooked modes of queer vocal consumption that do not contribute to an affirmative narrative of sexual liberation. Turning to the example of the chorister's voice not only challenges the prevalent idealization of the singing voice as a "queer space" but also allows for a renewed focus on the queer desire for those voices that reject and eschew-rather than affirm-the materiality of the body.

The first section of this article situates the fetishization of the chorister's voice among wider Victorian discourses of childhood innocence. Drawing upon late-Victorian vocal treatises, it examines the process of vocal training through which the "ethereal" voice of the Victorian chorister was produced. The second section turns to examine a number of literary texts that focus on the chorister's voice, drawing attention to the paradoxical manner in which the chorister's voice functions simultaneously to assert and disavow its embodied presence. The discussion then proceeds to a more detailed case study, examining the significance of the chorister's voice and body in the writings of Symonds. The final section turns particular attention on the figure of the "breaking" voice as an emblem of queer loss and transience.

In drawing attention to the problematics of such pederastic vocal consumption, the discussion that follows responds to recent work in queer studies calling for closer engagement with those shameful and embarrassing aspects of queer history that many in the queer community today might prefer to forget. ${ }^{8}$ Such an approach also serves to complicate and challenge established assumptions surrounding the consumption of Victorian musical culture more generally. Sacred music in England in the second half of the nineteenth century was often explicitly designed to promote moral self-discipline (typified, perhaps, by John Hullah's introduction of the sol-fa system) ${ }^{9}$ Scholars have generally taken as axiomatic the assertions of H. R. Haweis's influential Music and Morals (1871), which argues enthusiastically for the spiritual and moral edification promoted by Victorian church music. The idea that the experience of listening to music in cathedrals or chapels might elicit homosexual desires, perhaps unsurprisingly, finds no place in contemporaneous accounts of the cultural significance of Victorian religious music.

A closer attention to Symonds's fascination with the voice of the chorister also offers new perspectives on the relationship between aesthetic experience, intergenerational desire, and the emergence of queer subjectivity in the works of this central figure in the history of homosexuality. Recent work by Stefano Evangelista and Jana Funke has 
contributed much to scholarly understanding of Symonds's engagement with Hellenic ideas of pederasty and his concerns about age-appropriate relationships. ${ }^{10}$ However, both take as their starting point Symonds's ideas on sexual desire as presented in the mature works of his final years, written in the 1880 s and early $1890 \mathrm{~s}$. The discussion that follows focuses more closely on Symonds's experiences as a young man in the $1860 \mathrm{~s}$, as presented in his letters and his posthumously published Memoirs (1891). Funke's work acknowledges Symonds's attraction to "ephebic" youths but overlooks his arguably more problematic infatuation, as a young man, with prepubescent boys. ${ }^{11}$ In privileging Symonds's discomfort with intergenerational relationships in his later years over his earlier sexual attraction to children, Funke presents Symonds as a figure more easily assimilated to the norms of contemporary queer identity.

Discourses that eroticize the voice of the chorister are closely bound up with those that serve to legitimate the sexual abuse of children. While work by George Rousseau and others has done much to foreground the historical contingency of ideas of childhood and appropriate sexual behavior, it is necessary to emphasize that the power disparities between children and adults within such Victorian institutions as Anglican cathedrals and Oxford college chapels have nevertheless remained broadly similar across time. In terms of their young age, frequently lower-class background, and low position within an institutional hierarchy, choristers in Victorian England were clearly vulnerable to abuse. That there is not more historical evidence pointing to the sexual abuse of choristers in Victorian England seems more likely to be the result of institutional silencing, lack of reporting, and systematic cover-up than because it did not occur. More broadly, while there were well-established legal and social discourses relating to the sexual abuse of young girls in Victorian England, the sexual abuse of boys was almost never discussed. As Louise Jackson has noted, even when such abuse was recognized, it was "frequently side-stepped and concealed." ${ }^{12}$ Sexual assault experienced by boys was likely underreported due to the shame of its victims. In the context of Symonds's own life, Sean Brady has noted the conspiracy of silence that surrounded the resignation of Charles John Vaughan, headmaster of Harrow, following his sexual involvement with his pupils. ${ }^{13}$ The Victorian establishment was skillfully adept at protecting the reputations of those men implicated in the sexual abuse of children. One unfortunate effect of the archival silences that accompany such potential scandals is that an account of the eroticization of the chorister must 
depend almost exclusively on the written testimony of the men who fetishized the voices of these children. The sexual abuse of children within religious institutions such as the Anglican and Catholic churches continues to be a matter of grave concern today. ${ }^{14}$ It is only right that our engagement with the often-problematic relationship between adults and children in earlier historical periods continues to unsettle.

\section{Victorian Choristers and the Construction of Vocal Innocence}

Roland Barthes's essay "The Grain of the Voice" has been instrumental in drawing attention to the singing voice as an object of desire. For Barthes, the revelation of this bodily "grain," and the manner in which it opens up an intimacy between the singer and the listener, allows the singing voice to become a pleasurable object of erotic desire. "There is no human voice which is not an object of desire," Barthes suggests, because the singing voice represents "the materiality of the body emerging from the throat." ${ }^{15}$ Yet such an approach, while typically playful, is too rigidly schematic. Barthes's essay contributes much to his wider project of asserting the importance of pleasure and desire in the aesthetic encounter, but its framework remains an imperfect tool for analyzing the manifold cultural meanings attached to the singing voice. Certainly, it does nothing to account for the manner in which resolutely "grainless" voices, such as that of the chorister, become eroticized nonetheless. The training of the Victorian chorister's voice acts to eradicate all trace of the body from this voice. In doing so, it becomes perversely attractive to the Victorian listener as an object of fetishized innocence. Barthes fails to recognize the desire invested in those voices that efface the body, deny the embodied aspect of the voice, and resist corporeal intimacy between singer and listener. In order to fully account for the voice as an object of desire, it is necessary to turn to history to better understand the cultural meanings ascribed to such voices.

The angelic voice of the Anglican chorister is one of many emblems of childhood innocence manufactured by the Victorians. As Timothy Day has observed, the style of vocal production that characterizes the chorister-often described as "pure," "otherworldly," or "ethereal"-emerged only in the latter part of the nineteenth century. Such developments in English church music were closely connected to the influence of the Oxford Movement in the Anglican Church and its reassertion of a religious spiritualism and ritualism imbued with a sense of aesthetic beauty. ${ }^{16}$ A number of critics have explored the manner in which the 
religious and aesthetic discourses developed within such High Church and Anglo-Catholic traditions allowed for the articulation of queer desire. ${ }^{17}$ However, outside this narrow religious context, the development of the chorister's voice can be better understood as a product of the wider Victorian fetishization of childhood innocence.

Following from Philippe Ariès's seminal-though now much challenged-work on the historical emergence of the idea of the "child" in Centuries of Childhood (1960), the discursive construction of the "innocent child" in Victorian literature and visual culture has been influentially examined by a number of critics and cultural historians (e.g., Coveney, Avery, Rose, Higonnet, Gubar). James Kincaid's Child-Loving: The Erotic Child and Victorian Culture has influentially argued that those Victorian discourses which insist most resolutely on the innocence of the child in fact act to constitute the child as an object of erotic allure. Insisting on childhood purity and asexuality creates what Kincaid calls a "subversive echo": the endlessly circulating virtues of childhood innocence become erotically alluring because so rigorously proscribed. ${ }^{18}$

The innocence of the idealized Victorian child is almost always present in descriptions of a beautiful "pure" voice-a voice that soars out of the body, seemingly abandoning the embodied materiality that might taint it with desiring flesh. Frances Hodgson Burnett's Little Lord Fauntleroy (1884) - a novel in which, as Gillian Avery has noted, the word "innocence" recurs "like the beat of a drum"-is typical in this regard. ${ }^{19}$ Cedric, the titular "Little Lord," sings in church with a "pure, sweet, high voice rising as clear as the song of a bird." The idealized tableau is completed when "a long ray of sunshine [. . .] slanting through a golden pane of a stained glass window, brightened the falling hair about his young head." The child's aural and visual beauty has evidently found the sanction of divine providence, a view with which the reader is prompted to concur. Yet Hodgson Burnett's text also reveals the manner in which the child's voice becomes an object of adult desire. While the child sings, he is observed (and listened to) voyeuristically from the "curtain-shielded corner of the pew" by his grandfather, who "forgot himself a little" in "his pleasure in it." ${ }^{20}$ Despite the prevalence of the trope of vocal innocence, accounts of Victorian childhood have generally overlooked the significance of the singing voice as a key site in the construction of childhood innocence more broadly.

Significantly, this ethereal voice is the product of a mode of bodily training that often seeks to conceal the embodied origins of vocal production. Victorian vocal treatises on the voice of the chorister typically 
draw a distinction between the "head voice" (or the "thin register") and the "chest voice" (or the "thick register"). The main point of contention between these treatises relates to the extent to which each register should be used. Implicitly at stake here are questions of masculinity and embodiment: the more powerful, "throaty" sound is claimed by a masculinist "muscular Christianity," while the ethereal, disembodied voice is aligned with a High Anglicanism frequently castigated for its apparent effeminacy. Use of the head voice came to be one of the defining factors of the vocal style of the Anglican chorister. Proponents of the head voice described its sound as "pure," "sweet," and "limpid."21 The chest voice, in contrast, they deride as "rough," "throaty," "harsh," and "strident."22

G. Edwards Stubbs's Practical Hints on the Training of Choir Boys (1888) is typical of many late nineteenth-century vocal treatises in its demands for choir trainers to cultivate "pure and musical" head voices, over the "rough and boisterous" chest voice. ${ }^{23}$ Stubbs's later treatise-Current Methods of Training Boys' Voices (1898) - insists even more forcefully that the chorister should never sing with the chest voice. "It cannot be asserted enough," he stresses, "that the thick register of the boy voice is NOT what Nature designed for singing." The choirmaster should aim to "eliminate entirely" the use of the chest voice by gradually extending the use of the head voice downward into the lower register. ${ }^{24}$ Francis Howard's The Child-Voice in Singing (1898) assumes a position similar to that of Stubbs. The focus of his treatises is on promoting the use of the head voice; the chest voice, he concludes, is "wholly objectionable."25 Vocal innocence is contingent, then, on maintaining the illusion of disembodiment, on attaining a mode of vocal production that disguises the means of its own production in the lungs, throat, and diaphragm. Eliminating the "chest" voice is motivated by a desire to disguise those vocal colors that seem to have their origins in the depths of the material body, rather than the ethereal heavenly heights.

The disembodied phantasmagoria of the chorister's voice also accrues much of its cultural resonance due to its dialectical opposition to the sensuous, vibrato-laden voice of the opera singer, particularly that of the operatic soprano. ${ }^{26}$ In texts such as George du Maurier's Trilby (1895), the physical power of the operatic voice threatens to emotionally overwhelm its listeners. When the novel's protagonist, Little Billee, listens to an Italian tenor, his voice is presented in terms that ascribe to it a pleasurable power of physical coercion that verges on the sadomasochistic: "caught, surprised, rapt, astounded, shaken, tickled, teased, harrowed, tortured, tantalized, aggravated, seduced, demoralized." 27 
Meanwhile, the effect of the titular character's astoundingly virtuosic singing voice-a "monstrous development of the human larynx"reduces Little Billee to hysterical fits of sobbing. ${ }^{28}$ In Victorian novels, from George Eliot's Daniel Deronda (1876) to George Moore's Evelyn Innes (1898), the voice of the operatic soprano becomes so charged with sexual desire that it risks calling into question the virtue of the singer who produces it. ${ }^{29}$ In Eliot's verse drama Armgart (1871), the eponymous soprano's singing voice is presented as a means of release for powerful psychosexual nervous energies that might otherwise find expression only through violence and destruction:

\section{She often wonders what her life had been \\ Without that voice for channel to her soul. \\ She says, it must have leaped through all her limbs- \\ Made her a Mænad-made her snatch a brand \\ And fire some forest, that her rage might mount \\ In crashing roaring flames through half a land ${ }^{30}$}

As Koestenbaum has persuasively argued, such operatic voices became, in certain circles, "the sound of nineteenth-century sexuality." The nineteenth-century operatic voice vibrates with desire because it draws the listener deep into the recesses of the body through its visceral power and heft. In contrast, the voice of the chorister typically insists on disembodiment. It disavows the vibrating chest and throat, demanding a tone produced only in the head. In the process, it attains a state of what is resolutely referred to as "purity" - a vocal tone that implicitly connotes sexual innocence.

\section{The Desired Chorister in Victorian Literature}

Such disembodied vocal innocence is consistently foregrounded in representations of choristers and singing children in queer nineteenth-century literature. In "The Portrait of Mr. W. H." (1889), Oscar Wilde's narrator speculates that Willie Hughes-the apparent dedicatee of Shakespeare's Sonnets - may have started his life as a "delicate chorister of a Royal Chapel." Wilde's text offers a broadly historically plausible hypothesis that Hughes might have progressed from chorister to boy actor: in Elizabethan London, the so-called Children of the Chapel also intermittently performed as a troupe of child actors. ${ }^{32}$ But in focusing on Hughes's "clear and pure" voice, the text also mobilizes this history as a site of queer pederastic fantasy. ${ }^{33}$ Indeed, the association between 
queer sexual deviance and the desire for choristers was sufficiently well established by the late nineteenth century for it to become the target of thinly veiled satire in Robert Hichens's The Green Carnation (1894). Here, the corrupting affectations of Esme Amarinth and Lord Reggie are marked by, among other things, their predilection for beautiful young choristers. These boys are "magnetised" and "mesmerised" by the sight of the eponymous flowers these men wear in their lapels, falling "hopelessly in love." 34

Fantasy of a more explicitly sexual kind is at play in Ronald Firbank's Concerning the Eccentricities of Cardinal Pirelli (1926), in which the titular prelate meets his end while lasciviously chasing a chorister around the altar of his cathedral in the nude. While studying at Oxford, Gerard Manley Hopkins experienced similar desires, though he acted with more characteristic self-restraint. In the extensive catalog of confessed sins scrupulously recorded in his diaries, he admits in 1865 to "looking at a chorister at Magdalen, and evil thoughts." 35

The chorister frequently becomes an explicit object of sexual desire in what Timothy d'Arch Smith calls "Uranian" literature (that is, explicitly pederastic, often quasipornographic, literature of the late nineteenth and early twentieth centuries). ${ }^{36}$ Such literature often depicts the desire of a priest for a chorister in his charge. In Cuthbert Wright's poem "The Chorister" (1915), for example, the priest recognizes through "the yellow incense haze" of his church the face of a chorister whom he knew previously only as a "[s]treet-arab, gutter urchin, child / Incontinent and wild." The text simultaneously objectifies the child as a symbol of eroticized innocence while positing him as a sexually aware seducer: his face is "[w] hite-chinned, red-lipped and clear," but he is, in fact, a "surpliced faun"-a Pan-like figure of disguised erotic excess. ${ }^{37}$ A further dimension of erotic frisson is introduced by the class differential; the priest desires to "slum it" with a "street-arab" from the lower classes.

John Gambril Nicholson's The Romance of a Choir-Boy (1916) represents the apogee of pederastic fetishization of the voice of the chorister. Nicholson's text recounts the pursuit by Philip-a "hollow-cheeked and careworn" recent graduate from Magdalen College, Oxford-of the twelve-year-old chorister, Ted: "a wonderfully pretty boy for a rustic." 88 Semiautobiographical in its contents, the novel was written between 1896 and 1905 but privately published only in 1916. Philip's desire for the boy is justified in the text by the fact that Philip allows Ted to realize his musical potential: the working-class Methodist escapes his background to become an Anglican chorister. 
What distinguishes this text from other pederastic literature is its peculiarly intense focus on the aural aspects of desire. The music of the Anglican liturgy becomes associated with Philip's desire for young boys. While Philip voyeuristically observes Ted from a distance, the narrator notes: "A chant by Attwood was running in his head. An old Oxford episode made that chant very reminiscent of love to him. [. . .] Now he tried to fit a new personality to its haunting melody" (73). The text teasingly refuses to reveal the precise details of this "old Oxford episode," but it is clearly implied that Philip has fallen in love with a chorister before and that this attraction is closely connected with this boy's vocal performance. "As a Magdalen man," the narrator tells us later, "Philip knew what [. . .] good boys' voices were" (76-77). Here, an unidentified psalm chant by Thomas Attwood allows Philip to nostalgically recapture the intensity of his lost desire. He seeks to retain the thrill of this musical memory while substituting his previous object of desire for a new chorister, Ted.

Nicholson's text dwells insistently on the timbre of Ted's voice-it is "clear, sweet and mellifluous as a thrush's note"; a "glorious, pure soprano, soaring and vibrating" (76). This insistence on purity coincides with a less-than-subtle erotic suggestiveness. Philip listens "enraptured to a boy possessed of a natural organ second to none he had ever heard in his life" (77, emphasis mine). The pinnacle of Ted's musical achievement occurs at a service in St. Paul's Cathedral, attended by 1,300 choristers from around the country. The scenario seems purposefully designed as an indulgent pederastic fantasy. Ted has been chosen as principal treble at this grand service. Philip's reaction to Ted's solo-sung in his "superb soprano"-is similarly redolent of sexual excitement: "His eyes were closed, his lips apart, and he drew his breath with quick little inspirations; his hands tightly gripped the back of the chair in front of him; his body swayed a little as though he was in a dream" (91).

In a later episode, Philip listens "in a mellow haze of ecstasy" at evensong to "the boys' high penetrating treble [. . . soaring up like a tongue of flame on the top notes, and sinking back, as if in exhaustion, to the lower ones. [. . .] The effect was repeated-its repetition enhancing, and driving home the lovely cadences" (154-55, emphasis mine). The repeated mechanical movements of these penetrative voices, combined with their climactic "driving home" and postcoital "sinking [. . .] in exhaustion" leaves little to the imagination. In the text's final description of Ted's musical prowess, Nicholson even more explicitly elides the experience of listening to the child's voice with that of passive sexual pleasure. 
Philip revels in the "exquisite delicate ecstasy [...] of the penetrating modulated tones; the sharp enjoyment of a subtle sensuous sensation, that was half torture, half delight" (199, emphasis mine). Nicholson's style willfully evokes decadent aesthetic excess with his Wildean word choice ("exquisite," "delicate") and excessive sibilance.

What such texts share is a fixation on the chorister's voice as an emblem of desire that is disembodied: the child's voice is always presented in terms of its mobility and its dislocation from the material body that produces it. While Victorian fiction is replete with examples of the eroticized throat and mouth of the soprano and tenor, depictions of the chorister's voice insistently see it "soar" away from body. The desire for the voice of the chorister can be understood as part of a broader queer attachment to the disembodied and the immaterial-or, at least, an indulgence in the fantasy that sexual desire might be redeemed through its disembodied idealization into the aesthetic.

\section{John Addington Symonds: Music and Desire}

Such disembodied sexual idealization is central to the personal writings of John Addington Symonds. The young Symonds is preoccupied with the question of how one might idealize one's sexual desire-much under the spell of Plato, he is fixated with ideas of how queer sexual desire might leave behind the tainted desiring flesh and embrace instead an elevating disembodied spirit. In his experiences of music—singing in particular-he most pressingly faces the difficulty of achieving such an idealization: music at once speaks of the exalted, spiritual realm, while drawing him back continually to the visceral materiality of the desiring body.

The experience of music in Symonds's writings is frequently connected with the negotiation of intense sexual desire. "Music," he noted in his diary in 1871, "intensifies what is within those whom [one] loves"-and affords a power to heighten the force of desire. ${ }^{39}$ A lack of "music" functions repeatedly in his personal writings as a figure for the absence of sexual "spark." When Symonds reveals in his Memoirs the intense feelings of disgust, embarrassment, and humiliation that accompanied sexual intercourse with his wife, he bemoans that he "missed something in the music - the coarse and hard vibrations of sex, those exquisite agonies of contact." The only desire he feels for her is "too pure, too spiritual, too etherealized" (260). The physical materiality of music-its vibration in space, the manner in which it is felt by the body—-stands as a metaphor for desire expressed physically in sexual 
intercourse. In similar terms, one of Symonds's most overtly homoerotic texts, "In the Key of Blue" (1893), recruits a synesthetic language of Whistlerian impression, combining metaphors of the musical and the visual to celebrate the "symphony of hues" of the naked male body. ${ }^{40}$

Elsewhere, Symonds frequently alludes to musical examples in his letters to express the exhilaration, misery, and frustration of his unrequited or unconsummated same-sex desire. At the conclusion of a letter to Henry Graham Dakyns, Symonds laments the fact that Norman Moor - a school pupil with whom he has become intensely besotted-“just cares for me"; that is, is not sexually interested in him. Symonds gestures toward the "thunder obbligato" that concludes Robert Schumann's setting of Heinrich Heine's "Ich grolle nicht" in the song cycle Dichterliebe (1840). Schumann presents Heine's poem as an insistent declaration by a spurned lover that he will heroically endure his rejection, having realized the cruel true nature of his beloved. The repeated chords in the piano accompaniment on the subdominant and tonic with which the song closes ironically overperform this insistence, suggesting that the lover is merely disguising his emotional upset with a gesture of bravado. Symonds's reference is evidently a shared private joke between the correspondents, but by appending this reference to the close of his letter, he seems to acknowledge to Dakyns that he recognizes the slight ridiculousness of his melodramatic lament.

\section{Symonds and the Choristers: Bristol and Oxford}

Symonds's negotiations of music and desire are at their most fraught in his involvement with choristers. The chorister's voice, in Symonds's earliest writings, at first seems to represent an emblem of idealized beauty, capable of transmuting erotic desire into something nobler. Yet despite their apparent promise of ethereal disembodiment, such is the embodied reality of these voices that they continually draw Symonds back toward the temptations of the desiring flesh. The place of the chorister's voice in these private personal writings can be brought into sharper focus in the light of his published works, especially his poetry. Symonds's little-known sonnet "The Chorister" (1883) is particularly illuminating in this respect:

The Chorister

Snow on the high-pitched minster roof and spire:

Snow on the boughs of leafless linden trees:

Snow on the silent streets and squares that freeze 
Under night's wing down-drooping nigh and nigher.

Inside the church, within the shadowy choir,

Dim burn the lamps like lights on vaporous seas;

Drowsed are the voices of droned litanies;

Blurred as in dreams the face of priest and friar.

Cold hath numbed sense to slumber here! But hark,

One swift soprano, soaring like a lark,

Startles the stillness; throbs that soul of fire,

Beats around arch and aisle, floods echoing dark

With exquisite aspiration; higher, higher,

Yearns in sharp anguish of untold desire!

The sonnet is closely attentive to the movement of the voice in space. Here, the thrilling force afforded to the chorister's voice accrues through its contrast with the stillness that precedes it. The repeated inverted feet in the octave give a sense of sound being dampened down: the "silent streets" muffled in the fallen "snow," the voices "drowsed" in the haze of incense. The snow falling through the "night" becomes the softfeathered wing of a bird, "down-drooping" over the nestling cityscape. The flatness of this soundscape is captured in the dull assonances — "shadowy," "vapourous," "drowsed," "voices," "droned"-that render "numbed" sense in a state of "slumber." At the volta on line nine, the "swift soprano"-the chorister's voice-rises up to break the silence. The movement of this voice is energized not only through Symonds's sibilance ("soaring," "Startles the stillness; throbs that soul") but also from the iambic regularity of line ten-surprisingly buoyant after the metrical complexity of the lines that precede it. The sibilance that powers the chorister's voice to fill the "arch and aisle" leaves its traces also in the forceful and percussive inverted feet-"Startles," "Beats," "Yearns"- that express the "anguish" of the sestet.

In a way similar to Symonds's more private personal writings, the poem negotiates the boundaries between idealized and fleshly desire. The "throbs" and "beats" of the voice see it presented as a pulsating heart. Yet the expansive tumescence of this fleshly throbbing organ, as it "floods" the space of the "arch and aisle" and rises climactically "higher and higher," certainly hints also at an oddly phallic agency. The voice's "exquisite aspiration" indicates, for Symonds, both the delicate ascendance of the pure soul to paradise and the thrilling material presence of the singer's eroticized breath. This knowing ambiguity signals that the "untold desire" belongs not only to the voice, or to the child singer, but also to the Victorian fetishistic listener, unable to sustain the idealizing claims of disembodied vocal innocence. 
The "minster" of the sonnet is St. Stephen's Cathedral in Viennathe poem is based on one of Symonds's dream visions, recounted in "Winter Nights at Davos" in Italian Byways (1883), where it is made clear. The text nevertheless gains an indirect association with the Oxford college chapels of Symonds's youth through its mode of publication and material circulation. In autumn 1883 Symonds received a request from Thomas Herbert Warren-then a fellow at Magdalen College-to submit his work for inclusion in a new weekly newspaper, The Oxford Magazine. In response, he sent the magazine's editor three sonnets, including "The Chorister," that were subsequently to be collected in Vagabunduli Libellus (1884). The poem looks back to and draws on Symonds's experiences in Oxford as a much younger man.

From the years 1858 to 1863 , Symonds divided his time between his family home at Clifton Hall House, Bristol, and the University of Oxford. He regularly attended choral services at Bristol Cathedral and, in Oxford, at Magdalen and New College chapels and occasionally Christ Church Cathedral. Over the course of these years, Symonds engaged in a series of increasingly emotionally fraught relationships with a number of choristers he heard singing in these institutions.

When not studying at Oxford or at home in Clifton, Symonds spent much of his spare time over the course of these years visiting a succession of English cathedral cities. Between 1859 and 1862, his letters to his sister Charlotte detail attendance at services at the cathedrals of St. Paul's, London (January 1859), Durham, Bangor, and York (June 1859), Chester (August 1861), Norwich (October 1861), and Worcester (April 1862). Symonds's letters focus particularly on his musical experiences during these visits, dwelling in most detail on the musicianship and vocal quality of the choirs he hears. In Durham in June 1859, Symonds enthuses to Charlotte that the cathedral has "the best Trebles in England" (1:191). In Worcester in April 1862 he notes that "the choir [...] seems glorious \& will soon be finer still" (1:341). Chester's cathedral choir, in comparison, is "good-not brilliant but sound \& sturdy" (1:308). After a trip to Norwich Cathedral in October 1861, Symonds writes nostalgically to his sister: "I wonder what has become of the solo boys I heard sing 'Oh rest in the Lord' \& 'I know that my Redeemer liveth'. One of them was called Smith, I think" (1:313).

Symonds's first significant same-sex relationship was with Willie Dyer, a chorister at Bristol Cathedral. Symonds first met Dyer in April 1858, when Symonds was aged seventeen. Dyer, born in April 1843, was fourteen years old at the time. ${ }^{41}$ While their relationship was almost 
entirely unphysical, it was nevertheless one of the most significant of Symonds's life. From the perspective of the Memoirs, written over thirty years later, Symonds would reflect: "I have never felt the same unreason and unreasoning emotion for any other human being" (157). Significantly, his first encounter with Dyer occurred just after the "revelation" of his discovery of same-sex desire expressed in Plato's Phaedrus and Symposium. ${ }^{42}$ Symonds places a remarkable emphasis on the quality of Dyer's singing voice. His account in the Memoirs of his first encounter with Dyer in Bristol Cathedral is as follows:

$[\mathrm{M}] \mathrm{y}$ eyes fell on a chorister who sat nearly opposite the stall which I had taken. His voice charmed me by its sharp ethereal melancholy. In timbre and quality it had something of a wood instrument. [. . .] As I gazed and listened through the psalms and service and litany, I felt that a new factor had been introduced into my life. The voice dominated. But the boy who owned the voice seemed the only beautiful, the only flawless thing I had ever seen. (156)

Symonds draws attention to both the visual and the aural nature of his desire for the child. His rapt accounts of his visits to the cathedral return repeatedly to these twin attractions: "[l] ooking at the boy in church, hearing him sing"; "kneeling in cathedral stall, listening to antiphons, gazing on beautiful faces" (156-57, emphasis mine). Here, Symonds's visual objectification of the child is clear. Yet, as the text insists, it is the voice that "dominated." Symonds's fixation on the child's voice presents it as an object independent of the child's appearance or physical body: the voice that "dominated" is conceptually separated from "the boy who owned the voice." Indeed, the voice is afforded its own disembodied agency. It moves from "[h] is voice"-tied closely to the body from which it is emitted-to "[t]he voice." Symonds invokes the familiar trope of the voice as a means of seduction-" $[\mathrm{h}]$ is voice charmed me." The voice is the active subject of the sentence here, not the child, and it thus becomes an abstracted seductive force. In this way, the text can insist on the "flawless" sexual innocence of the child-it is the voice, not the child, that acts to seduce-while simultaneously investing the child's voice with sexual desire. The text leaves the nature of this voice's "domination" ambiguous. It is the domination of the aural over the visual, but also the domination of the voice over the listener-the rendering of the listener joyfully passive. The voice's capability to "charm" is attributed to its "sharp ethereal melancholy." Such disembodied ethereality might be seen to reflect the transcendent mysticism of Tractarian 
Anglicanism (associated by the young Symonds with what he experienced as the "aesthetic ecstasy [. . .] called religion") or the imperative expressed in Plato to idealize bodily sexual desire through the aesthetic (158). Yet Symonds is also drawn toward the voice's evocation of pain and sadness. Here the voice's signification shifts again: the voice functions as an intimate revelation of Dyer's (apparent) inner self. The melancholy of the voice becomes key to its enticing quality: Symonds is drawn to Dyer by a sense of shared sorrow.

In 1860 Symonds-now twenty years old-became infatuated with another Bristol Cathedral chorister, Alfred Brooke. In contrast to his love for Dyer, Symonds's intense desire for this fourteen-year-old found expression only in his imagination. Nevertheless, the textual traces of this unfulfilled desire provide useful insights into Symonds's fetishization of the singing voice. Symonds's relationship with Brooke has been the subject of some confusion in accounts of Symonds's life: Phyllis Grosskurth presents Symonds's sexual fantasies relating to Brooke as if they recount actual events; ${ }^{43}$ Rousseau conflates Alfred Brooke with Willie Dyer, erroneously suggesting that Symonds fell in love with Brooke while both were pupils at Harrow; ${ }^{44}$ Brady incorrectly states that "Alfred Brook" [sic] was "a fellow undergraduate" at Oxford. ${ }^{45}$ Given such confusion, it is necessary to clarify the nature of Symonds's relationship with Brooke.

Alfred Brooke was born in Bristol in 1846. It appears that Symonds first met him in September 1859, at the home of Reverend John Guthrie. The party was attended by a number of clergy associated with Bristol Cathedral, along with the choristers. The group performed music for the assembled guests. Symonds's account of the evening notes that "we had nice Madrigals etc.: poor little Brooke came rather to grief in 'As pants [the] hart'” (Symonds to Charlotte Symonds, September 15, $1859,1: 204-6) .{ }^{46}$ Symonds seems subsequently to have strongly associated Brooke with the words of Psalm 42 or, perhaps, musical settings of this text.

During university vacations from his studies in Oxford, Symonds returned home to Bristol, where he regularly attended services at Bristol Cathedral. It was here that he first became infatuated with Brooke. Symonds's Memoirs recount:

I fell violently in love with a cathedral chorister called Alfred Brooke. The passion I conceived for him differed considerably from my affection for Willie Dyer. It was more intense, unreasonable, poignant-at one and the same time more sensual and more ideal. I still think that this boy had the most beautiful face I ever saw and the most fascinating voice I ever heard. (193) 
Symonds characteristically draws attention to the beauty of both Brooke's voice and to his physical appearance. That his voice is "fascinating"-in its contemporary meaning, spellbinding or enchanting — casts the boy as akin to a Siren, whose erotically alluring voice entices the pacified, weak-willed listener. Through his voice, the child becomes the seducer of the adult.

Incorporated in the Memoirs is what Symonds calls a "prose dithyramb" - an ecstatic Dionysian hymn of praise-recounting his intense desire for Brooke. Symonds asserts in the Memoirs that the passage was composed "in 1865 when the tyranny had been overlived but still vibrated in memory" (195). That the "tyranny" of Symonds's desire for Brooke should "vibrate" suggests something of its connection to the "vibrating voice" that instigated this desire. The passage's biblical diction, archaic syntax, and repetitive use of the first-person pronoun, alongside its joyfully self-assertive homoeroticism, represent Symonds at his most Whitmanesque, and it seems likely that it was composed in the wake of Symonds's discovery of the poet he viewed as a revolutionary proponent of liberated individualism.

But while the dithyramb's exalted tone of Old Testament prophecy certainly echoes Whitman, its biblical allusions can also be placed within the Anglican musical tradition with which Symonds was closely familiar. The dithyramb bears an epigraph from the Latin Vulgate-"Quemadmodum desiderat cervus ad fontes aquarum," the opening verse of Psalm 42 (in the King James Version: "As the hart panteth after the water brooks"). In heading the dithyramb with an epigraph from scripture, the text consciously echoes the form of the Anglican sermon, familiar from regular church attendance, but also through widely circulated printed copies. Each of the sermons in John Keble's Sermons for a Christian Year (1827), for example, begins with a single verse of scripture, which introduces the passage upon which the sermon is based. Part of this undoubtedly reflects Symonds's desire to reclaim something of the spiritualism of Tractarian Anglicanism in order to incorporate it into a more enthusiastic, sexually liberated vision of what he called the "illimitable symphony of cosmic life." 47 Symonds's dithyramb subsequently contains nothing that approaches the equivalent of a theological exegesis one would expect from a sermon, but it does proceed to draw specific parallels between the psalm and Symonds's experience of his desire for Brooke ("I thirst for him as the hart panteth after water brooks" [Memoirs, 195]). The "brook" referred to in Psalm 42 is, of course, a playful pun on the name of Alfred Brooke himself. 
In contrast to those texts that dwell on the disembodied ethereality of the chorister's voice, Symonds here focuses on the visual delight in Brooke's body, listing each detail of his anatomy with an intensity reminiscent of Whitman at his most rhapsodic. Brooke's voice leads him into the body. This lengthy description presents Brooke as if engaged in the act of singing: the text peers through the child's open lips into the "humid" space of his "large red [. . . m mouth"; inside it sees his "vibrating voice," an animated larynx; it dwells on the child's "athletic throat and well-formed breast," from which this voice originates. There is "invitation in the ringing voice; a readiness to grant favours": the intense, assertive power of the child's singing is a signal of his erotic availability, his apparent willingness to engage sexually with the listener. Later, the seductive force of the voice is asserted once again: "the fascination of his voice and breathing drowsed me." Within its erotically charged context, the voice's power to impose upon the listener a "drowsed" tiredness suggests the alluring pleasures of sexual passivity: the voice renders the listener dominated, vulnerable, powerless (196-97).

In Symonds's dithyramb, the metaphor of "panting" becomes another image associated with the eroticized voice. The rapid rise and fall of the diaphragm, the shallow inspiration of the lungs, the swift movement of breath: panting animates the same anatomical machinery used by the singing voice, but it does so in a way that undoes the rigid bodily discipline demanded by vocal technique. In the psalm, such "panting" is prompted by the deer's thirst, a metaphor for the soul's longing for divine salvation. Here, the desire for the divine is transformed into something explicitly sexual: it is the panting of sexual excitement, of coital exertion.

Symonds's erotic revelry is inspired not just by Brooke's voice and body but also draws upon his recollection of performances of Anglican choral music. References to liturgical performances of settings of Psalm 42 occur repeatedly in his letters around this time. In April 1859 Symonds heard "a nice service at Magd[alen]" that included Handel's setting of "As pants the hart." "It was well sung," he noted in a letter to Charlotte, "but I have often heard it done better" (April 1859, 1:182). In December 1860 Symonds attended a service at Christ Church Cathedral expressly to hear Mendelssohn's "As Pants the Hart" sung by Frederick William Pacey, a thirteen-year-old chorister. As noted above, it was the same setting of this text that Symonds heard Brooke struggle to sing in September 1859. In June 1858 Symonds wrote to Charlotte that the "dear little boy" Willie Dyer had sent him the music for "As Pants the Hart" "as arranged in solo \& septette" (1:149). This liturgical choral 
music is recollected by Symonds as part of the process of "mental masturbation" - the phrase is his own-that motivated his erotic writings (168).

It should be noted that, despite the intensity of Symonds's feelings for Brooke, it is unclear how well he knew him. The Memoirs insist that the erotic "prose dithyramb" is entirely the product of "dreams and visions," an assertion supported by the marginal note scrawled in frustration on Symonds's manuscript: "Would to God that I had fraternized with him! Would to God that I had sought and he had suffered that carnal union" (203). Given Symonds's insistence that his desire for Brooke "runs like a scarlet thread through [his] diaries of several years," it is surprising that he never mentions Brooke in his letters to Henry Graham Dakyns. In other respects, their correspondence discloses in frank detail the persistent, often tortured desire these men felt for children and young adolescents (e.g., the children of Tennyson, their school pupils Norman Moor, Arthur Carré, and Cecil Boyle). ${ }^{48}$ It seems unlikely that Symonds's relationship with Brooke progressed beyond the level of private fantasy; had it done so, it seems highly likely that Symonds would have discussed it with Dakyns, with whom he is typically frank in his correspondence.

It was at Oxford that Symonds's involvement with choristers was finally to cause a scandal. The circumstances of this episode have been dealt with at length by George Rousseau, so they need only be summarized here. In 1862 Charles Shorting, a former friend of Symonds who held a grudge against him, wrote to the fellows of Magdalen Collegewhere Symonds had recently been elected as a probationary fellowaccusing Symonds of harboring impure desires for the choristers at Magdalen. Symonds had indeed developed an intense attraction to an eleven-year-old chorister, Walter Goolden. Precisely what attracted Symonds to Goolden remains unclear, though letters from Symonds to his sister suggest that he admired his voice-he is referred to in passing as "a good treble" (November 9, 1862, 1:370). There is nothing to suggest that Symonds acted on his desires. In the investigation that followed, Symonds was exonerated. Nevertheless, he emerged from the proceedings thoroughly humiliated, and the emotional turmoil of the events took a severe toll on his health. He resigned his fellowship and left Oxford shortly after. Rousseau carefully situates the episode within the intensely homosocial atmosphere of Victorian Oxford, noting Symonds's position in an "Arcadian" pederastic subculture in which choristers were frequently objectified by older men. He ultimately concludes that attraction to choristers may be connected to class disparity, but he overlooks the 
significance of the fact that these children were most closely associated with their singing voices.

During his time at Oxford, Symonds's letters often dwell on the performances and voice quality of trebles to the exclusion of the other musical performers at the services he attends. In October 1858 he enthuses about a rendition of "How Beautiful Are the Feet" from Handel's Messiah at Magdalen, "sung very nicely by a good treble" (1:168). Later that term, he attends "a splendid service at New College" that included "I Waited for the Lord" from Mendelssohn's Lobgesang sung "by two boys in unison," which provides, he says, "a pleasing effect" (November $1858,1: 171)$. In the course of his correspondence, he repeatedly praises the vocal beauty of an assortment of Magdalen choristers without once offering an assessment of the standard of singing by the lay clerks or, indeed, of the playing of Magdalen's organist. While the arrival at Magdalen in January 1860 of John Stainer as organist passes without comment, Symonds's letters are otherwise closely attentive to changes in musical personnel. Around December 1860, for example, he sorrowfully laments the fact that New College has "lost [. . .] their best treble" and that another favorite chorister, Henry Homer Page, has departed from Magdalen for Rugby School (1:217-18).

It is clear from Symonds's Memoirs, and from historical work undertaken by Rousseau, that Symonds was one of a number of students who were in some way attracted to choristers in Oxford in the 1860s. The proximity of choristers to older students was certainly of some concern to Oxford college authorities around this time. ${ }^{49}$ When Symonds first arrived in Oxford, his friends included Edward William Urquhart, who, he reports, "had high church proclivities and ran after Choristers." His friend Randell Vickers was "a man of somewhat similar stamp." "In their company," he notes, "I frequented antechapels and wasted my time over feverish sentimentalism" (Memoirs, 170). Symonds also became "intimate friends" at Oxford with Charles Shorting, a friendship terminated when the latter's "conduct with regard to boys, especially the choristers at Magdalen, brought him into serious trouble" (178). Symonds later blamed Shorting for bringing his "peculiar atmosphere of boy-love into [his] neighbourhood" around 1862 (180). As shown above, there is ample evidence to show that Symonds harbored strong desires for prepubescent boys long before this point in time, though an important distinction is that Shorting appears to have acted on such desires much more readily. ${ }^{50}$

Symonds's Memoirs suggest that one function of the consumption of chorister voices was to strengthen homosocial relationships between male 
undergraduates in "Arcadian" subcommunities at Oxford, based on shared sexual and aesthetic tastes. Symonds's accounts of listening to choristers as an undergraduate appear not to be solitary experiences but rather communal ones in which he was joined by other young Oxford contemporaries. Parallels might be drawn between Symonds's fetishization of the voice of the chorister while at Oxford and his eroticized aesthetic consumption of photographic nudes of young men in his later life. Stefano Evangelista has noted Symonds's interest in photography in the late 1880 s, particularly in nudes of young men in a Mediterranean setting, by artists such as Wilhelm Von Gloeden. Symonds was an avid collector of such images and circulated them among friends with similar sexual tastes (such as Henry Graham Dakyns, Edmund Gosse, and Charles Kains-Jackson). While Evangelista is careful to note the problematic issues of exploitation that such photographs raise, he also suggests that they might have nevertheless played a positive role in establishing discourses of homosexual emancipation. Such photographs, he suggests, acted as "a material referent to cement a shared sexual identity"; in doing so, they "helped to develop a language about male homosexuality that is based on desire and eroticism rather than medicine ('inversion') or the ancient world ('pederasty')".$^{51}$ If the consumption and circulation of quasipornographic images can promote the development of community among sexual minorities, communal musical listening might also provide a forum in which such groups establish shared aesthetic codes, tastes, and practices. The consumption of choristers' voices in 1860s Oxford can be understood as an early example of the aestheticism of the following decades, which, as Matt Cook has argued, "provided a model for a complex identity based on beauty and the senses, rather than on social and cultural conformity or biological determinism." ${ }^{22}$. Comparison might be drawn with the episode in E. M. Forster's Maurice, in which a group of young men listen to Tchaikovsky's Sixth Symphony (Pathétique) reproduced on the pianola in the privacy of their rooms at Cambridge. ${ }^{53}$ The shared consumption of music, which, as the text later makes clear, was explicitly understood as an encoding of homosexual desire, becomes a means for fostering an emergent sense of queer community.

\section{A Boy's Voice Broken}

While the communal consumption of choristers' voices in Victorian Oxford can be understood to provide an affirmative basis for shared queer sexual identities, it also represents an investment in an aesthetic 
object defined by its transience and impermanence. The chorister's voice attains a special attraction due to the knowledge that its beauty cannot be sustained. In this respect, it takes its place alongside a panoply of cherished emblems of loss that populate queer Victorian literature: A. E. Housman's Shropshire lads, doomed to an early grave; Walter Pater's "diaphanous types," preordained to victimhood; Vernon Lee's spectral eighteenth-century operatic voices. ${ }^{54}$ The chorister's voice functions, in this respect, as a figure of the negativity that theorists such as Heather Love and Lee Edelman have identified as a pervasive psychic substrate in queer culture. Far from being a vehicle for the "reproductive futurism" that Edelman convincingly locates in Victorian culture's idealization of "the Child," the vocal purity of the chorister is underwritten by its refusal of future possibility-the inevitable break that occurs with the arrival of puberty.

The fact that the chorister's voice is always doomed to "break" is central to the manner in which it becomes eroticized. In Victorian vocal treatises the transition made by the boy's voice around puberty is always figured as sudden and momentous. Discourses placing heavy emphasis on the breaking voice reinforce the process through which the child is posited as categorically distinct from the adult. Following Kincaid, it is precisely this relentless emphasis on the child's difference from the adult that sees the "innocent child" become eroticized. While this trope is applied to both the speaking and the singing voice, its results are portrayed as particularly dramatic in the context of the latter. As present-day vocal trainers have emphasized, the conception of the boy's voice suddenly "breaking" fails to acknowledge the gradual nature of the change in the child's voice. Choir trainers today are more likely to recognize the fact that the boy's voice begins the process of change at the very onset of puberty. ${ }^{55}$ In contrast, Victorian treatises on the chorister tend to emphasize an abrupt, catastrophic vocal failure. George Martin's account is representative in this respect:

He is admitted to the choir, and for about two years he appears to be of no appreciable value. At eleven, or thereabouts, perhaps, his voice begins to show signs of development and promise. He continues to improve until he is about twelve, then possibly for two years or so his voice is at its best. Then comes total collapse. ${ }^{56}$

The hyperbolic conclusion of Martin's narrative of vocal development — "then comes total collapse"-is humorous both in its melodrama and its sheer certitude. The contrast between this short, blunt sentence 
and the longer, more grammatically complex preceding sentences provides added emphasis. The latter contains none of the hesitant qualifiers of the sentences that it follows ("about," "thereabouts," "perhaps," "possibly"). This break is sudden, final, irreversible, cataclysmic. Such rhetoric reflects more general Victorian conceptions of puberty, which is often figured as a sudden, radical change: "a complex revolution is effected in the human economy at the ages of puberty"; "genital organs suddenly and astonishingly develop" and "sexual desires are awakened." As Kincaid has noted, while in earlier periods childhood seemed to be defined by ideas of dependence, by the Victorian period, the new dividing line appeared to relate to puberty. The suddenness of puberty allows the Victorians to draw a clear line between the "child" and the "nonchild."

In this manner, the figure of the "broken" voice can be understood to act within wider discourses on childhood to reinforce the idea of the child as a class distinct from the adult. Discussions of the "breaking" voice frequently note that it coincides not just with the other secondary physical changes that mark the onset of puberty but also with the "moral and intellectual change" understood to signal the transition to adulthood. ${ }^{58}$ Symonds himself reflects such a position in "A Problem in Modern Ethics" (1891), when he notes that "at the age of puberty [. . .] a boy distinguishes himself abruptly from a girl, by changing his voice and growing hair on parts of the body where it is not usually found in women." Puberty is figured as an "abrupt" transition. Indeed, in Symonds's consideration of "the mysterious dubiety of what we call sex," he suggests that it is precisely the very abruptness of gender differentiation at puberty that can lead to "sexual inversion." 59

Symonds's letters while at Oxford often note with sadness the departure of favorite choristers from the chapels he attends. His fascination with this moment of vocal transition is most evident in his sonnet "A Boy's Voice Broken" (1884). Symonds's sonnet not only reveals the elision of vocal failure with the loss of innocence but also allows for a broader consideration of the way in which the materiality of the singing voice is mediated through the technology of verse. Yopie Prins's discussion of the complexities with which Victorian lyric poetry transforms the speaking voice into metrical utterance-what she calls "voice inverse"-is instructive in this regard. ${ }^{60}$ Prins's focus is on uncovering how closer attention to Victorian musical settings of poetry might reveal alternative strategies for imagining the metrical "voicing" of poetry. But her work also alerts us to the manner in which verse can foreground 
the awkward transformations of the material voice, as in Symonds's sonnet.

\section{A Boy's Voice Broken}

Summer hath come! The world is ripe for song!

Pant forth thy passionate pain, thou nightingale!

Brown moonlight fills the broad ambrosial vale,

Where deep-embowered I wait and listen long!

So cried the boy. When, hark, the hurrying throng

Of thick notes preluding that final wail!

Thrilled by the sound divine, his lips grew pale;

Some god unknown within his heart was strong.

Then silence fell. He, soaring on the wings

Of song, poured his soul forth in rivalry:

Till, at heaven's height, where the rapt spirit springs

By one quick bound up to infinity,

The boy's voice failed. Love's hour had come. The lute

On which Love plays, must first be smitten mute.

In its contest between the singing nightingale and the singing child, Symonds's sonnet invokes a broader dialectic between the transcendent lyric voice (of which such birdsong is a familiar trope) and the embodied material voice. In doing so, it reflects what Marion Thain has identified as something of a preoccupation of late nineteenth-century poetry. Here, the boy is prompted into song through his "rivalry" with the "sound divine" of the nightingale. But there is a tension between the Romantic imagery of idealization ("the wings / Of song," the "rapt spirit," the rise of the voice to "infinity") and a more somatically grounded language of the body. The nightingale's song-a curiously sensuous and breathy "pant"-is registered through an affective "thrill" on the "pale [...] lips" and the stirred "heart" of the boy as he listens. The penultimate line of the poem makes clear that the boy's loss of voice equates to the loss of innocence: "The boy's voice failed. Love's hour had come. The lute [...]" (144). The "voice inverse" of failed material speech is registered through its metrical mediation. The caesuras introduced by the full stops act to emphasize the import of the vocal break, drawing a stark division between childhood innocence and sudden adolescent sexual awakening. The meter draws the reader to place stresses on each of the monosyllables of "boy's voice failed." Only after the literal and metrical break of the caesura does the line fall back into regular iambs. The innocent child (and the idealized lyric voice) remain, through this metrical strategy, ultimately insulated from sensuous vocal materiality. 
The chorister's voice remains untainted by the sexual and is thus, perversely, maintained as an object of eroticized innocence.

The "thick notes" of the nightingale are also those of the boy's voice as it teeters on the brink of failure, reflecting a common trope in Victorian writing about the breaking voice. The child's voice is understood to grow in strength and beauty up to the point at which it breaks. "For the year or two preceding the break of voice," Howard enthuses, "the brilliance and power of boys' voices, especially in the higher tones, is often phenomenal." 61 The idea recurs repeatedly in Symonds's writings. In a letter to Horatio Brown praising the "deep incommunicable spirit-speaking power of voices," Symonds dwells on his sensuous attraction towards "a contralto of extraordinary force and volume and vibration": "a boy's voice on the point of breaking proved by its incomparable thrill" (July 21, 1880, 2:641-42). In "A Problem in Greek Ethics," Symonds compares the "bloom of youth" celebrated by the Greeks_- "that [moment of] corporeal beauty, unlike all other beauties of the human form"-to the fullness of the boy's voice just before it breaks. This climax of "corporeal loveliness," he suggests, "marks male adolescence no less triumphantly than does the male soprano voice upon the point of breaking." It is the "very evanescence" of this "bloom" that makes it so very desirable to the Greeks, Symonds argues, "since nothing more clearly characterizes the poetic myths which adumbrate their special sensibility than the pathos of a blossom that must fade" (111-12). Symonds's desire for the voice of the chorister might be understood in similar terms.

Indeed, as both Kincaid and Jackson have noted, many accounts of Victorian pederasty are motivated by a desire to resist the idea of transience, to fix the child in a state of perpetual innocence. ${ }^{62}$ "The prosaic fact that children do not stay children," Kincaid observes, "takes on an enormous psychological and poetic force in the imaginings of childlove." 63 The most effective way of infinitely postponing the arrival of adulthood is through death, thus the popularity among Victorian authors of killing off the innocent children that populate their texts. Such a pattern is borne out in Victorian narratives invoking the figure of the innocent chorister, often tales of religious instruction published for mass consumption by organizations such as the Society for the Promotion of Christian Knowledge. Texts such as the anonymous Michael the Chorister (ca. 1870) and Little Walter: The Lame Chorister (1885) and Bingley Roel's Chorister Jim: The Yorkshire Choir Boy (1897) follow a predictable, morally instructive narrative arc: an innocent child overcomes his 
tendency toward occasional (if fundamentally mild) naughtiness; he turns toward God in an act of repentance; he becomes the victim of some sort of violence or illness; he places his trust in divine providence; ultimately, he dies peacefully, resigned to any misfortune he may have faced. The chorister in such Victorian fictions never lives long enough for his voice to break. The point at which the voice changes is invested with such significance because it stands as a point of metaphorical death. As a category of identity, the chorister cannot exist after the voice changes, for the chorister is defined by his pure, prepubescent vocal tone. The voice of the chorister becomes cherished, desired, fetishized because it is doomed to perish.

A close examination of Victorian literary texts, personal writings, and vocal treatises demonstrates that the voice of the chorister was never solely the natural product of the child's body. Vocal purity, so closely bound up with Victorian ideals of childhood innocence, was the deliberate product of training techniques designed to create the impression of the voice as naturally disembodied. It is the apparently disembodied nature of such vocal innocence that paradoxically saw it become such a prevalent object of sexual desire in Victorian pederastic writings. By confronting the often-unsettling nature of the Victorian aesthetic consumption of the chorister's voice, it becomes possible to move debates in queer musicology beyond their redemptive impulse and consider more carefully the complexities of encounters with the singing voice. Such an approach challenges queer scholars and musicologists to reassess assumptions about the ways in which the singing voice is conceived as a site at which queer subjectivities and communities come into being, calling for a more nuanced account of the dynamics of power at play in the desiring musical encounter.

\section{NOTES}

This work was supported by the Arts and Humanities Research Council as part of the Northern Bridge Doctoral Training Partnership.

1. "And $O$ those children's voices singing in the dome" (my translation).

2. Symonds, Letters, June 13, 1892, 3:691, April 27, 1891, 3:571. All subsequent references to this edition are noted parenthetically in the text.

3. Symons, "Paul Verlaine," 510; Moore, Confessions, 111. 
4. Symons, "Decadent Movement," 858.

5. See Dame, "Unveiled Voices"; and Wilbourne, "Queer History."

6. Pulham, "The Castrato and the Cry," 435.

7. Miller, Bringing Out Roland Barthes, 31-32.

8. See Gould, "The Shame of Gay Pride"; and Halberstam, "The Killer in Me."”

9. Potter, Vocal Authority, 81; Gatens, Victorian Cathedral Music, 33-40.

10. Evangelista, "Platonic Dons."

11. Funke, “We Cannot Be Greek Now,'” 140.

12. Jackson, Child Sexual Abuse, 100-101.

13. Brady, Masculinity and Male Homosexuality, 163-70.

14. Ashley, How High Should Boys Sing?, 81-82. The Independent Inquiry into Child Sexual Abuse, investigating the Church of England and other institutions, was announced by the UK government in July 2014 and remains ongoing.

15. Barthes, "Music, Voice, Language," 279; "Listening," 255.

16. Gatens, Victorian Cathedral Music, 2-10.

17. See Hanson, Decadence and Catholicism; Hilliard, "UnEnglish and Unmanly"; and Roden, Same-Sex Desire.

18. Kincaid, Child-loving, 4-5.

19. Avery, Nineteenth Century Children, 178.

20. Burnett, Little Lord Fauntleroy, 116-17.

21. Roberts, Treatise, 5; Howard, The Child-Voice, 28; Curwen, The Boy's Voice, 59; Stubbs, Practical Hints, 46, 83.

22. Howard, The Child-Voice, 3; Behnke and Browne, The Child's Voice, 33.

23. Stubbs, Practical Hints, 36.

24. Stubbs, Current Methods, 3.

25. Howard, The Child-Voice, 7.

26. For an account of the emergence of this vocal style in the nineteenth century, see Potter and Sorrell, A History of Singing, 109-48.

27. Du Maurier, Trilby, 166.

28. Du Maurier, Trilby, 221.

29. For the place of the female operatic singer in Victorian literature and culture more broadly, see Weliver, Women Musicians.

30. Eliot, Armgart, 117.

31. Koestenbaum, The Queen's Throat, 155.

32. For further background on choristers in early modern England, see Mould, The English Chorister, 113-26.

33. Wilde, "The Portrait of Mr. W. H.," 332.

34. Hichens, The Green Carnation, 105. 
35. Hopkins, Diaries, Journals and Notebooks, 337.

36. D'Arch Smith, Love in Earnest, 179.

37. Wright, "The Chorister," 38.

38. Nicholson, Romance of a Choir-Boy, 18, 9. All subsequent references to this edition are noted parenthetically in the text.

39. Symonds, Memoirs, 387. All subsequent references to this edition are noted parenthetically in the text.

40. Symonds, "In the Key of Blue," 15; see also Maxwell, "Whistlerian Impressionism," 234-42.

41. Grosskurth, John Addington Symonds, 42-49; Brady, Masculinity and Male Homosexuality, 166-70. Brady's account is inaccurate in suggesting that Symonds was twenty when he first met the seventeen-year-old Dyer (169). The precise date of their first meeting (April 10, 1858) is stated in Symonds, Memoirs, 156.

42. For the central importance of Plato to Symonds's understanding of same-sex desire, see Dowling, Hellenism and Homosexuality; and Evangelista, "Platonic Dons."."

43. Grosskurth, John Addington Symonds, 58-60.

44. Rousseau, "John Addington Symonds," 177.

45. Brady, Masculinity and Male Homosexuality, 171.

46. While the editors of Symonds's letters suggest that this was "probably a local youth who was an amateur singer," it seems more likely-given the assembled company-to have been Alfred Brooke, who was at that time a chorister at Bristol Cathedral. The music Brooke sung was likely the second movement of Felix Bartholdy-Mendelssohn's setting of Psalm 42, "Meine Seele dürstet nach Gott."

47. Symonds, Whitman, 35.

48. For further details of Symonds's relationship with Dakyns, see Booth, "Same-sex Desire."

49. See Wollenberg, Music at Oxford, 201; D’Ancona, "'Every One of Us,'” 500.

50. See Rousseau, "John Addington Symonds."

51. Evangelista, "Aesthetic Encounters," 93.

52. Cook, London, 96.

53. Forster, Maurice, 28.

54. See Robbins, “A Very Curious Construction””; Khalip, "Pater's Sadness"; Vicinus, "AA Legion of Ghosts."”

55. Ashley, How High Should Boys Sing?, 41-56.

56. Martin, The Art of Training Choir Boys, 21. 
57. Ryan, The Philosophy of Marriage, 143, 67; Drysdale, Elements of Social Science, 65, emphasis mine.

58. Behnke and Browne, The Child's Voice, 97.

59. Symonds, "A Problem in Modern Ethics," 180.

60. Prins, "'Break, Break, Break' into Song” and "Voice Inverse."

61. Howard, The Child-Voice, 22.

62. Jackson, Child Sexual Abuse, 114.

63. Kincaid, Child-loving, 226.

\section{WORKS CITED}

Ariès, Philippe. Centuries of Childhood. Translated by Robert Baldick. Harmondsworth: Penguin, 1973.

Ashley, Martin. How High Should Boys Sing? Gender, Authenticity and Credibility in the Young Male Voice. Farnham: Ashgate, 2009.

Avery, Gillian. Nineteenth Century Children: Heroes and Heroines in English Children's Stories, 1780-1900. London: Hodder and Stoughton, 1965.

Barthes, Roland. "The Grain of the Voice." In Image Music Text, translated by Stephen Heath, 178-89. London: Fontana, 1977.

- . "Listening." In The Responsibility of Forms: Critical Essays on Music, Art, and Representation, translated by Richard Howard, 245-60. New York: Hill and Wang, 1985.

—. "Music, Voice, Language." In The Responsibility of Forms: Critical Essays on Music, Art, and Representation, translated by Richard Howard, 278-85. New York: Hill and Wang, 1985.

Behnke, Emil, and Lennox Browne. The Child's Voice. London: Sampson Low, Marston, Searle and Rivington, 1885.

Booth, Howard J. "Same-sex Desire, Ethics and Double-mindedness: The Correspondence of Henry Graham Dakyns, Henry Sidgwick and John Addington Symonds." Journal of European Studies 32 (2002): 283-301.

Brady, Sean. Masculinity and Male Homosexuality in Britain, 1861-1913. Basingstoke: Palgrave Macmillan, 2005.

Burnett, Frances Hodgson. Little Lord Fauntleroy. New York: Charles Scribner's Sons, 1886.

Cook, Matt. London and the Culture of Homosexuality, 1885-1914. Cambridge: Cambridge University Press, 2003.

Coveney, Peter. The Image of Childhood; the Individual and Society: A Study of the Theme in English Literature. 2nd ed. Harmondsworth: Penguin, 1967.

Curwen, John Spencer. The Boy's Voice: A Book of Practical Information on the Training of Boys' Voices for Church Choirs. London: J. Curwen \& Sons, 1891.

Dame, Joke. "Unveiled Voices: Sexual Difference and the Castrato." In Queering the Pitch: The New Gay and Lesbian Musicology, edited by Philip Brett, Elizabeth Wood, and Gary C. Thomas, 139-53. 2nd ed. New York: Routledge, 2006. 
D’Ancona, Matthew, et al. “Every One of Us Is a Magdalen Man': The College, 1854-1928." In Magdalen College Oxford: A History, edited by L. W. B. Brockliss, 387-566. Oxford: Magdalen College, Oxford, 2008.

D'Arch Smith, Timothy. Love in Earnest: Some Notes on the Lives and Writing of English "Uranian" Poets. London: Routledge and Kegan Paul, 1970.

Day, Timothy. "English Cathedral Choirs in the Twentieth Century." In The Cambridge Companion to Singing, edited by John Potter, 123-32. Cambridge: Cambridge University Press, 2000.

Dowling, Linda. Hellenism and Homosexuality in Victorian Oxford. Ithaca: Cornell University Press, 1994.

Drysdale, George. Elements of Social Science. London: Truelove, 1886.

Du Maurier, George. Trilby. 1895. Edited by Dennis Denisoff. Oxford: Oxford University Press, 2009.

Edelman, Lee. No Future: Queer Theory and the Death Drive. Durham: Duke University Press, 2004.

Eliot, George. Armgart. 1871. In Collected Poems, edited by Lucien Jenkins, 115-51. London: Skoob, 1989.

—. Daniel Deronda. 1876. Edited by Graham Handley and K. M. Newton. Oxford: Oxford University Press, 2014.

Evangelista, Stefano. "Aesthetic Encounters: The Erotic Visions of John Addington Symonds and Wilhelm Von Gloeden." In Illustrations, Optics and Objects in Nineteenth-Century Literary and Visual Cultures, edited by Luisa Calè and Patrizia Di Bello, 87-104. Basingstoke: Palgrave Macmillan, 2010.

—. "Platonic Dons, Adolescent Bodies: Benjamin Jowett, John Addington Symonds, Walter Pater." In Children and Sexuality: From the Greeks to the Great War, edited by George Rousseau, 206-30. Basingstoke: Palgrave Macmillan, 2007.

Firbank, Ronald. Concerning the Eccentricities of Cardinal Pirelli. London: Richards, 1926.

Forster, E. M. Maurice. 1913. Edited by P. N. Furbank. London: Penguin, 2005.

Funke, Jana. "We Cannot Be Greek Now': Age Difference, Corruption of Youth and the Making of Sexual Inversion." English Studies 94, no. 2 (2013): 139-53.

Gatens, William J. Victorian Cathedral Music in Theory and Practice. Cambridge: Cambridge University Press, 1986.

Gould, Deborah B. "The Shame of Gay Pride in Early AIDS Activism." In Gay Shame, edited by David M. Halperin and Valerie Traub, 221-55. Chicago: University of Chicago Press, 2009.

Grosskurth, Phyllis. John Addington Symonds: A Biography. London: Longman, 1964.

Gubar, Marah. Artful Dodgers: Reconceiving the Golden Age of Children's Literature. Oxford: Oxford University Press, 2008.

Halberstam, Jack. “The Killer in Me Is the Killer in You': Homosexuality and Fascism." In The Queer Art of Failure, 147-72. Durham: Duke University Press, 2011.

Hanson, Ellis. Decadence and Catholicism. Cambridge, Mass.: Harvard University Press, 1997.

Haweis, H. R. Music and Morals. London: Strahan, 1871. 
Hichens, Robert. The Green Carnation. London: Heinemann, 1894.

Higonnet, Anne. Pictures of Innocence: The History and Crisis of Ideal Childhood. London: Thames and Hudson, 1998.

Hilliard, David. "UnEnglish and Unmanly: Anglo-Catholicism and Homosexuality." Victorian Studies 25, no. 2 (1982): 181-210.

Hopkins, Gerard Manley. Diaries, Journals and Notebooks. Vol. 3 of The Collected Works of Gerard Manley Hopkins. Edited by Lesley Higgins and Michael F. Suarez. Oxford: Oxford University Press, 2015.

Howard, Francis E. The Child-Voice in Singing. New York: Novello, Ewer, 1898.

Jackson, Louise A. Child Sexual Abuse in Victorian England. London: Routledge, 2000.

Keble, John. Sermons for the Christian Year. 12 vols. London: Parker, 1875.

Khalip, Jacques. "Pater's Sadness." Raritan 20, no. 2 (2000): 136-58.

Kincaid, James R. Child-loving: The Erotic Child and Victorian Culture. New York: Routledge, 1992.

Koestenbaum, Wayne. The Queen's Throat: Opera, Homosexuality and the Mystery of Desire. New York: Da Capo Press, 2001.

Little Walter: The Lame Chorister. London: Joseph Masters, 1885.

Love, Heather. Feeling Backward: Loss and the Politics of Queer History. Cambridge, Mass.: Harvard University Press, 2007.

Martin, George C. The Art of Training Choir Boys. London: Novello, Ewer, 1877.

Maxwell, Catherine. "Whistlerian Impressionism and the Venetian Variations of Vernon Lee, John Addington Symonds, and Arthur Symons." Yearbook of English Studies 40, nos. 1-2 (2010): 217-45.

Michael the Chorister. London: John and Charles Mozley, [1870?].

Miller, D. A. Bringing Out Roland Barthes. Berkeley: University of California Press, 1992.

Moore, George. Confessions of a Young Man. 3rd ed. London: Swan Sonnenschein, 1889.

- Evelyn Innes. London: Fisher Unwin, 1898.

Mould, Alan. The English Chorister: A History. London: Hambledon Continuum, 2007.

Nicholson, John Gambril. The Romance of a Choir-Boy. London: privately printed, 1916.

Potter, John. Vocal Authority: Singing Style and Ideology. Cambridge: Cambridge University Press, 1998.

Potter, John, and Neil Sorrell. A History of Singing. Cambridge: Cambridge University Press, 2016.

Prins, Yopie. "'Break, Break, Break' into Song." In Meter Matters, edited by Jason David Hall, 105-34. Athens: Ohio University Press, 2011.

—. "Voice Inverse." Victorian Poetry 42, no. 1 (2004): 43-60.

Pulham, Patricia. "The Castrato and the Cry in Vernon Lee's Wicked Voices." Victorian Literature and Culture 30, no. 2 (2002): 421-37.

Robbins, Ruth. "'A Very Curious Construction': Masculinity and the Poetry of A. E. Housman and Oscar Wilde." In Cultural Politics at the Fin de Siecle, edited by Sally Ledger and Scott McCracken, 137-59. Cambridge: Cambridge University Press, 1995. 
Roberts, J. Varley. A Treatise on a Practical Method of Training Choristers. London: Frowde, 1898.

Roden, Frederick S. Same-Sex Desire in Victorian Religious Culture. Basingstoke: Palgrave Macmillan, 2002.

Roel, Bingley. Chorister Jim: The Yorkshire Choir Boy. London: Jarrold, 1897.

Rose, Jacqueline. The Case of Peter Pan; or, The Impossibility of Children's Literature. Basingstoke: Macmillan, 1993.

Rousseau, George. "You Have Made Me Tear the Veil from Those Most Secret Feelings': John Addington Symonds Amidst the Children.” In Children and Sexuality: From the Greeks to the Great War, edited by George Rousseau, 173-99. Basingstoke: Palgrave Macmillan, 2007.

Ryan, Michael. The Philosophy of Marriage. Philadelphia: Haswell, Barrington and Haswell, 1837.

Stubbs, G. Edward. Current Methods of Training Boys' Voices. London: Novello, Ewer, 1898.

—. Practical Hints on the Training of Choir Boys. London: Novello, Ewer, 1897.

Symonds, John Addington. “A Boy's Voice Broken.” In Vagabunduli Libellus, 144. London: Kegan Paul, Trench, 1884.

—. "The Chorister." In Vagabunduli Libellus, 90. London: Kegan Paul, Trench, 1884.

—. "In the Key of Blue." In In the Key of Blue and Other Essays, 1-16. London: Macmillan, 1893.

- The Letters of John Addington Symonds. Edited by Herbert M. Schueller and Robert L. Peters. 3 vols. Detroit: Wayne State University Press, 1967-69.

- The Memoirs of John Addington Symonds: A Critical Edition. Edited by Amber K. Regis. Basingstoke: Palgrave Macmillan, 2016.

—. "A Problem in Greek Ethics." 1883. In John Addington Symonds (1840-1893) and Homosexuality: A Critical Edition of Sources, edited by Sean Brady, 41-121. Basingstoke: Palgrave Macmillan, 2012.

. "A Problem in Modern Ethics." 1891. In John Addington Symonds (1840-1893) and Homosexuality: A Critical Edition of Sources, edited by Sean Brady, 125-208. Basingstoke: Palgrave Macmillan, 2012.

- Walt Whitman: A Study. London: John C. Nimmo, 1893.

—. "Winter Nights at Davos." In Italian Byways, 332-50. London: Smith, Elder, 1883.

Symons, Arthur. "The Decadent Movement in Literature." Harper's New Monthly Magazine 87 (1893): 858-67.

—. "Paul Verlaine." National Review 19 (1892): 501-15.

Thain, Marion. The Lyric Poem and Aestheticism: Forms of Modernity. Edinburgh: Edinburgh University Press, 2016.

Verlaine, Paul. "Parsifal." 1886. In Selected Poems, edited and translated by Martin Sorrell, 155. Oxford: Oxford University Press, 1999.

Vicinus, Martha. "AA Legion of Ghosts': Vernon Lee (1856-1935) and the Art of Nostalgia.” GLQ 10, no. 4 (2004): 599-616. 
Weliver, Phyllis. Women Musicians in Victorian Fiction, 1860-1900: Representations of Music, Science and Gender in the Leisured Home. Aldershot: Ashgate, 2000.

Wilbourne, Emily. "The Queer History of the Castrato." In The Oxford Handbook of Queerness and Music, edited by Fred Maus and Sheila Whiteley. Oxford: Oxford University Press, 2018.

Wilde, Oscar. "The Portrait of Mr. W. H.” 1889. In Complete Works of Oscar Wilde, 30250. London: Harper Collins, 2003.

Wollenberg, Susan. Music at Oxford in the Eighteenth and Nineteenth Centuries. Oxford: Oxford University Press, 2001.

Wright, Cuthbert. "The Chorister.” In One Way of Love, 38. London: Elkin Matthews, 1915. 